$1-2008$

\title{
The Importance of "Focusness": Focus Groups as a Means of Collection Management Assessment
}

\author{
Barbara J. Strauss \\ Cleveland State University, b.strauss@csuohio.edu \\ Fran Mentch \\ Cleveland State University, f.mentch@csuohio.edu \\ Carol Zsulya \\ Cleveland State University, c.zsulya@csuohio.edu
}

Follow this and additional works at: https://engagedscholarship.csuohio.edu/msl_facpub

Part of the Library and Information Science Commons, and the Other Psychology Commons

How does access to this work benefit you? Let us know!

\section{Publisher's Statement}

"This is an Author's Accepted Manuscript of an article published in Collection Management 2008, available online: http://www.tandfonline.com/10.1080/01462670802158047."

\section{Original Citation}

Mentch, F., Strauss, B., \& Zsulya, C. (2008). The Importance of "Focusness": Focus Groups as a Means of Collection Management Assessment. Collection Management, 33(1/2), 115-128.

\section{Repository Citation}

Strauss, Barbara J.; Mentch, Fran; and Zsulya, Carol, "The Importance of "Focusness": Focus Groups as a Means of Collection Management Assessment" (2008). Michael Schwartz Library Publications. 7.

https://engagedscholarship.csuohio.edu/msl_facpub/7

This Article is brought to you for free and open access by the Michael Schwartz Library at EngagedScholarship@CSU. It has been accepted for inclusion in Michael Schwartz Library Publications by an authorized administrator of EngagedScholarship@CSU. For more information, please contact library.es@csuohio.edu. 


\title{
The Importance of "Focusness": Focus Groups as a Means of Collection Management Assessment
}

\author{
Fran Mentch \\ Barbara Strauss \\ Carol Zsulya
}

\begin{abstract}
In order to assess the Library's collection, the Collection Development Assessment Team at Cleveland State University used focus groups to complement the information gathered in LibQUAL $+{ }^{\mathrm{TM}}$. Groups of undergraduates, graduates, and faculty participated in four separate focus groups. All groups reported they were essentially satisfied with the collection but also wanted better local collections and used OhioLINK to supplement their research; fewer users also utilized the rich resources of the public library systems. In keeping with previous surveys, all groups wanted more full-text available electronically, faster access to materials, and a more navigable website. It appeared that the more sophisticated the user, the more satisfied they were with the collection. The Special Collections focus group would like to have more materials
\end{abstract}

Fran Mentch, MSW, MLIS, is Social and Behavioral Sciences Librarian (E-mail: f.mentch@csuohio.edu); Barbara Strauss, MLS, is Head of Technical Services (E-mail: b.strauss@csuohio.edu); Carol Zsulya, MSLS, is Head of Collection Management and Business/Economics Librarian and Communication Librarian (E-mail: c.zsulya@ @ csuohio.edu), all at Cleveland State University, 2121 Euclid Avenue, Cleveland, OH 44115-2214.

The authors wish to thank Shelly Freyn, Research Associate, Strategic Business Center and Thomas Whipple, $\mathrm{PhD}$, Chair and Professor of Marketing, and Director of the Strategic Business Center at Cleveland State University. 
digitized, improved accessibility to the collection and website, and increased interaction with the community to heighten awareness of the collection and in order to gather more primary materials for the collection.

KEYWORDS. Assessment, collection development, focus groups, LibQUAL + ${ }^{\mathrm{TM}}$, Cleveland State University

\section{INTRODUCTION}

A professional baseball player was once interviewed and asked about how he managed to play so well in the last game. He replied, "It's focusness." "Focusness" is no easy task, and is especially difficult for any organization that is as large and as human as Cleveland State University. According to the Book of Trends (Cleveland State University 2006), Cleveland State is a public university with eight colleges, about 15,000 graduate and undergraduate students; 8,280 of them attend fulltime. Average student age is 29.4 and the median age is 26 . A commuter school, the university has fewer than 1,000 students living in on-campus housing. Cleveland State University has two libraries, the University Library and the Cleveland-Marshall College of Law Library; these libraries share resources, but their collection management teams function independently. The University Library also has a department called Special Collections that gathers historic materials about the city of Cleveland and the surrounding metropolitan area.

A hallmark of successful organizations is that the workers all paddle in the same direction. This article addresses Cleveland State University Library's effort to assess its collection and to do so in keeping with the overarching University goals and strategic plan. University Library participates in the campus-wide assessment program coordinated by the Office of Student Learning Assessment and models the Library's strategic plan on the University's strategic plan (Cleveland State University).

\section{BACKGROUND}

University Library is committed to the success of its users. To measure user satisfaction, University Library conducted LibQUAL + ${ }^{\mathrm{TM}}$ surveys in 2002, 2003, 2005 and 2007. On its website LibQUAL+ TM is described as "a suite of services that libraries use to solicit, track, under- 
stand, and act upon users' opinions of service quality. These services are offered to the library community by the Association of Research Libraries (ARL). The program's centerpiece is a rigorously tested webbased survey bundled with training that helps libraries assess and improve library services, change organizational culture, and market the Library. The goals of LibQUAL + ${ }^{\mathrm{TM}}$ are to:

- Foster a culture of excellence in providing library service

- Help libraries better understand user perceptions of library service quality

- Collect and interpret library user feedback systematically over time

- Provide libraries with comparable assessment information from peer institutions

- Identify best practices in library service

- Enhance library staff members' analytical skills for interpreting and acting on data."

The Library has taken steps to work on continuous improvement in several areas, including improving the Library's collection. Among the findings that were evident in each set of results was the faculty rating of the collection and access to it as "poor"; while graduate students sometime rated the collection "poor." Since questions in LibQUAL+ TM surveys do not allow respondents to explain their responses, the Collection Development Assessment Team lacked more specific information about the responses and wanted to learn more about the meaning of the LibQUAL $+{ }^{\mathrm{TM}}$ survey results.

During fiscal year 2006-2007 the Collection Development Assessment Team, which includes the authors of this article, was created as a subset of the Library's Assessment Team and charged to make a significant contribution to meeting one of the University's strategic goals, "academic excellence." The University defines academic excellence as improving undergraduate education, enhancing graduate education and research, and facilitating signature programs. The Library works with the other departments, schools and colleges to meet Cleveland State University's overall strategic goals. This collaboration and cooperation makes it possible for the University to increase in quality and succeed financially as an educational institution. The Library defines one of its slices of "academic excellence" as providing quality resources to meet the needs of users. The Collection Development Assessment Team decided to explore the concerns of the academic community about the Library's collection as expressed in the LibQUAL+TM results. 
University Library is a member of a large statewide consortium of libraries called OhioLINK. Through this consortium the Cleveland State University faculty and students have access to 45.3 million items and over 100 databases. The Library's collection has to meet local needs and at the same time develop the consortium's collection. The Library's users also have access to an incredible resource-the Cleveland Public Library, the third largest public research library in the country. In addition, Cleveland Public Library is also part of the CLEVNET consortium of thirty-one public library systems in nine counties. Because Cleveland State University is primarily a commuter school the public libraries are important to its students. The Collection Development Assessment Team wanted to learn how students and faculty interact with the on-site collection, the collections of OhioLINK, the Cleveland Public Library and their own local public library.

LibQUAL+TM, a quantitative research tool, complements focus groups, a qualitative research tool. Surveys are good at gathering breadth of data; focus groups are good at gathering depth of data. Focus groups are used by libraries to evaluate a wide variety of topics, everything from the use of union catalogs to SFX (Hartley 2006; Wakimoto 2006) and libraries frequently use this combination of the tried and true LibQUAL + TM survey and focus groups when evaluating their services and resources (Becher 2005; Weber 2006). University Library used LibQUAL + ${ }^{\mathrm{TM}}$ four times in the past five years and found it to be an especially useful instrument in the consortial environment as most members of OhioLINK also use LibQUAL+TM. Thus Cleveland State can compare its performance over time and against peer institutions in the consortium.

The Collection Development Assessment Team was fortunate to be able to use a University resource to develop and facilitate the focus groups. Dr. Thomas W. Whipple and Graduate Assistant, Shelly L. Freyn, from Cleveland State's Nance College of Business Administration worked with the team to develop questions that would be asked in the focus groups. The questions were about perceptions of the $\mathrm{Li}$ brary's collection, both in print and online; use of the collection for research; what frustrations were faced and how frequently when using the collection; and what other resources were used, including OhioLINK and public libraries. The information gathered from the focus groups was analyzed and will be considered with other assessments of the collection to help make the best decisions about resources. 


\section{METHODOLOGY}

The Collection Development Assessment Team began work on the focus groups in fall of 2006. The groups were held in March 2007, and the results were incorporated in the Collection Management 2007 Assessment Report which was submitted with other library assessment reports to the Office of Student Learning Assessment on May 31, 2007. From inception to completion, the process took eight months, and followed commonly accepted guidelines for this type of research (Olson 2006, 13-14).

The assessment team was composed of five librarians, all of whom have assigned subject areas and are involved in selecting and purchasing materials. Three of the librarians have additional administrative responsibilities; one of these librarians served as the team leader. The team leader is also the subject librarian for the Nance College of Business Administration and the School of Communication. Her relationships with faculty and staff there facilitated the logistics and the success of this research. She met with the director and associate director of the Library to clarify goals and details and then approached Dr. Whipple about facilitating the focus groups. He was enthusiastic, agreed to conduct the focus groups, and enlisted Ms. Freyn to help with the other aspects of the project. As part of his preparation, Dr. Whipple asked for the results of any other surveys or focus groups conducted by the Library. He and his graduate assistant met several times with the team leader to plan and work out the details of the project. About five weeks before the focus groups were held, the graduate assistant met with all the team members to review questions and expectations.

The team was given permission to use the university's Communication Research Center that includes a meeting room with a one way mirror, and an adjoining observation room with videotaping equipment. All participants were asked to sign an informed consent form, indicating that their privacy would be respected and their names would not be released and that the videotape would not be shared with anyone other than principal investigators. Student assistants videotaped the focus groups and made DVDs of the sessions; team members and other interested library staff who could not observe in vivo were still be able to "watch" the focus groups. In addition, the graduate assistant acted as the "scribe" and took notes in the observation room while the focus groups were conducted.

The questions were initiated by suggestions from team members; eventually the list was refined with final corrections made by the professor conducting the focus groups. The questions were used as a tool to 
share and identify the library resources that are useful for members of the focus groups and to identify any challenges in utilizing resources. A script of the final list of questions is found in Figure 1, Focus Group Questions.

The decision was made to have four different groups, one composed of undergraduates, one of graduate students, one of faculty and one of users of the Special Collections. The team wanted to get participating students and faculty from various colleges, that is, College of Liberal Arts and Social Sciences, College of Education and Human Services, College of Science and the Maxine Goodman Levin College of Urban Affairs. Team members and subject librarians submitted names of faculty members, who were invited to attend the focus group. Those faculty members were asked to suggest names of undergraduate and graduate students to participate in focus groups; team members also submitted names of students to be invited. Since Special Collection is heavily used by the community and has an ever-expanding and diverse user group, a separate focus group was held to gather information from these users; faculty were invited from the Department of Civil and Environmental Engineering, Department of English, Department of History, and the Department of Urban Studies. Although the target was to have 10-12 members in each focus group, the average size was six. Lunch and a gift card were provided to all participants as an inducement.

\section{FINDINGS}

As a component part of their service to this project, Dr. Whipple and Ms. Freyn summarized the results of the focus groups, identified patterns of themes and made recommendations to the team based on a synthesis of information.

A summary of the findings to the focus group questions is given in Table 1. Overall, the members of the focus group were satisfied with the collection, depending on how individuals defined collection. Some defined the collection as that of Cleveland State University, to others the collection was OhioLINK. Some defined the collection as a combination of print and electronic resources, while for others the collection was only electronic. Because of this basic satisfaction, the conversations in all groups moved to the topic of convenience and increasing the speed of accessing materials; this is a common concern of library users (Ryan and Valverde 2005). Some felt the length of time users had to wait for 


\section{FIGURE 1. Focus Group Questions}

\section{The CSU resources}

- What is your overall impression of the library's book collection?

- What is your overall impression of the online collection?

- What electronic resources or texts have you used through the library? What electronic resources or texts would you like to see added?

- Identify the key resources you use when doing research.

- What do you use?

- Why do you use these resources?

- What do you like most about them?

- What do you like least about them?

- How did you find about the resources you use?

- Who influenced you to choose these resources?

\section{Resource Challenges}

- Identify frustrations when attempting to find resources for a project.

- Give examples of frustrations (what did you do, where did you look?)

- How frequently do these issues occur?

\section{Do you use other resources?}

- Why?

\section{IV. "Ideal World"}

- If you were going to do research in an "ideal world", what would you need for resources?

- Do you see CSU acquiring these resources?

\section{Special Collections}

- Have you used materials (primary source materials) from our Special Collections department to support your work?

- What did you find most useful, what did you find that these collections lacked?

- What other venues do you use to find primary source materials?

- What other materials would you like to see in this collection?

Source: Questions used for the focus group sessions conducted by Dr. Thomas W. Whipple, Chair and Professor of Marketing and Director of the Strategic Business Center and Shelly Freyn, Research Associate Business Center, both at Cleveland State University held at Cleveland State University, Cleveland, Ohio on March 21, 27-28, 2007.

OhioLINK materials or interlibrary loan materials to arrive was an inconvenience. There was some frustration that other OhioLINK libraries have greater resources, that is, neighboring Case Western Reserve University and Ohio State University, although there seemed to be limited understanding that these institutions are not peer institutions. 
TABLE 1. Summary of Findings for Faculty, Graduate and Undergraduate Students

\begin{tabular}{llll}
\hline & Faculty & Graduate & Undergraduate \\
\hline $\begin{array}{l}\text { Print collection } \\
\text { impression }\end{array}$ & $\begin{array}{l}\text { Acceptable-no major } \\
\text { issues on accessing } \\
\text { available resources. }\end{array}$ & $\begin{array}{l}\text { Felt that there was a } \\
\text { limited supply of texts } \\
\text { and collections were } \\
\text { conservative (based } \\
\text { only on professor } \\
\text { interests). Also over } \\
\text { half of their books }\end{array}$ & $\begin{array}{l}\text { Perception is that it is } \\
\text { limed and outdated; } \\
\text { choice for research-use } \\
\text { library to typically pick }\end{array}$ \\
& & up interlibrary loans.
\end{tabular}

\section{Electronic collection impression}

\author{
Use OhioLINK \\ frequently; adequate.
}

half of their books

were through

interlibrary loan via

OhioLINK would like

more texts in CSU

library.

Felt library's web page Primarily use CSU

was not overly

user-friendly; would

like better access to

information that is

interdisciplinary. Some

resources did not sup-

ply more than abstracts.

How do you seek Start with CSU and out information OhioLINK, then go to outside libraries (CWR, OSU, alum libraries).

Start with CSU as the first resource for research, followed by OhioLINK and finally, Cleveland Public Library System.

Larger than bricks and mortar; perceive all resources as the "library" includes electronic journals, Ohio link (electronic is the preference).

Felt the actual library was limited on its supply of books and did not appreciate having to do much of their research through interlibrary loans.

\section{University Library overall impression}

Electronically, resources seemed adequate, but a lot of trial \& error effort in finding what you need.

\section{Comments}

Need a process and communication system on budgets, requests and training.
Graduate assistants' large emphasis on "next" generation students and their lack of knowledge as to what a library is; there will be a strong emphasis on only electronic resources as references. library web page, some OhioLINK through CSU-in general, meets needs.

Start with CSU library web page, then Google Scholar.

Same as faculty. Primarily use electronic resources; if can't get what they need... move onto another reference source under CSU webpage.

Several comments about training and its helpfulness; utilized CSU library page, but felt that it was not overly user friendly. 
The results that Whipple and Freyn summarized on the Special Collections focus group are represented in Table 2, Summary of Comments on Cleveland Memory and Special Collections. The team gained valuable information about Special Collections particularly because that department is not studied extensively by LibQUAL $+\mathrm{TM}$. Users were very happy with the help they receive from staff, and were interested in improvements in accessibility to the collection and website which would increase their ability do more research independently. They also suggested that Special Collections be marketed to the community and that additional resources be gathered from the community and added to the collection. They made the specific suggestion that Special Collections have a scanner that can be taken out to the community in order to gather more primary materials.

The most significant findings come with Whipple and Freyn's identification of patterns in the focus group discussions, as represented in Table 3, Recommendations Based on "Patterns" from Focus Groups' Responses. Whipple indicates that "information [...] is based on "patterns' from all the focus groups responses-some recommendations may not be related to the actual resources, but they are indirectly linked." These big four-future expenditures on electronic resources, website design, resource acquisition training and marketing the University Library-are much more specific themes than the general comments found in LibQUAL+TM.

TABLE 2. Summary of Comments on Cleveland Memory and Special Collections

\begin{tabular}{ll}
\hline Collection impression & $\begin{array}{l}\text { Noted cataloging and indexing issues in trying to find specific } \\
\text { items in the collection. }\end{array}$ \\
Electronic impression & $\begin{array}{l}\text { Cleveland Memory Search engine is inadequate; very difficult } \\
\text { to use. }\end{array}$ \\
Overall impression & $\begin{array}{l}\text { Very impressed with the staff and their knowledge, resourceful } \\
\text { ness. Would like to see more resources to aid in organizing the } \\
\text { collections for easier access. }\end{array}$ \\
Comments & $\begin{array}{l}\text { Would like to see more of the collections digitized and available } \\
\text { electronically. Also would like the ability to take a scanner on } \\
\text { site to outside Cleveland organizations to copy and bring re- } \\
\text { sources into the University collections. }\end{array}$ \\
\hline
\end{tabular}

Source: Data from focus group sessions conducted by Dr. Thomas W. Whipple, Chair and Professor of Marketing and Director of the Strategic Business Center and Shelly Freyn, Research Associate, Strategic Business Center, both at Cleveland State University held at Cleveland State University, Cleveland, Ohio on March 21, 27-28, 2007. 
TABLE 3. Recommendations Based on "Patterns" from Focus Groups' Responses

\begin{tabular}{|c|c|c|}
\hline Area & Recommendation & Comments \\
\hline $\begin{array}{l}\text { Future } \\
\text { expenditures }\end{array}$ & $\begin{array}{l}\text { Focus attention and expenditures } \\
\text { on the electronic collections } \\
\text { for the future of the library. }\end{array}$ & $\begin{array}{l}\text { Based on all focus group } \\
\text { responses, research typically } \\
\text { begins with the University Library } \\
\text { website (or Cleveland Memory } \\
\text { for Special Collections) and not } \\
\text { with the print collections. Also } \\
\text { highly noted were OhioLINK and } \\
\text { interlibrary loan. }\end{array}$ \\
\hline $\begin{array}{l}\text { Website } \\
\text { design }\end{array}$ & $\begin{array}{l}\text { Give ongoing attention to the } \\
\text { University Library webpages } \\
\text { and improving "user-friendliness." }\end{array}$ & $\begin{array}{l}\text { Although the groups initially went } \\
\text { to the CSU website, some } \\
\text { mentioned challenges with } \\
\text { accessing information, not } \\
\text { knowing how to find resources or } \\
\text { in general, not knowing what the } \\
\text { site provided. The library may } \\
\text { want to strive for continual } \\
\text { improvement and ease of use of } \\
\text { this site. }\end{array}$ \\
\hline $\begin{array}{l}\text { Resource } \\
\text { acquisition } \\
\text { training }\end{array}$ & $\begin{array}{l}\text { Develop a training program or strat- } \\
\text { egy to elevate the awareness of } \\
\text { available resources; how to access } \\
\text { them and how to add new resources. }\end{array}$ & $\begin{array}{l}\text { Training programs designed } \\
\text { specifically for faculty on attain- } \\
\text { ing resources (e.g. on-line jour- } \\
\text { nals) should be established. }\end{array}$ \\
\hline $\begin{array}{l}\text { Marketing the } \\
\text { University } \\
\text { Library }\end{array}$ & $\begin{array}{l}\text { University Library should position } \\
\text { itself as being larger than bricks } \\
\text { and mortar. }\end{array}$ & $\begin{array}{l}\text { Increase awareness and } \\
\text { educate students/faculty about } \\
\text { the extensive collection of elec- } \\
\text { tronic resources University } \\
\text { Library provides. }\end{array}$ \\
\hline
\end{tabular}

Source: Data from focus group sessions conducted by Dr. Thomas W. Whipple, Chair and Professor of Marketing and Director of the Strategic Business Center and Shelly Freyn, Research Associate, Strategic Business Center, both at Cleveland State University held at Cleveland State University, Cleveland, Ohio on March 21, 27-28, 2007.

\section{DISCUSSION}

Freyn's notes from the sessions yielded information that librarians intuitively knew over a period of time but did not have data to confirm. The subjective nature of assessing impressions is imprecise and anecdotal. The controlled environment of a focus group responding to set questions leads to a clearer understanding of respondent's impressions. The team identified several topics that resonated with current library operations, programs or plans.

All users in the groups perceive the Library as having a physical presence that is dwarfed by its virtual presence. The focus group leader 
suggested the Library be marketed as a "keyhole" to the world of information. Overall, the more sophisticated the users, the more satisfied they were with the collection. These users are well past the learning curve and know how to use all aspects of the consortial environment of OhioLINK and the public library system.

All groups wanted improvements to the website design, although it seems that some remarks under the general heading of "website" may include remarks about interfaces that are purchased and other services not created by library staff.

Whether or not the Library has copies of textbooks is another common concern that was mentioned in the groups. Students want them for their own use. One faculty member mentioned that the Library used to have a policy of having a copy of all textbooks on reserve; this policy has been discontinued. They were interested in exploring policies at other institutions. It seemed users continue to struggle with the legitimacy of the cost of textbooks as part of higher education.

Faculty members were more interested in issues of how materials were selected and purchased, what they cost, and the limits on purchasing their requests. Some stated they realize they should make specific requests for materials, but do not make the effort to do so. Regularly asking faculty if they have any books or materials they want the Library to purchase was mentioned as a way to improve the collection. Faculty also wanted more materials that would help them in their research; they use their alma mater and on-site visits to other universities and archives for their research. This finding echoes the results reported in the literature (Weber 2006). They also talked about wanting more training programs about library resources and how to use them.

Members of the graduate student focus group were frustrated by difficulty finding books on the shelves. Interestingly, the graduate students were concerned about the research skills of the undergraduates and the need to have everything in electronic format. One comment was, "They don't even know what a library is!" Likewise, faculty felt that "if students can't get it in one click they move on." These comments seemed to reflect a pyramid of concern, from librarians to faculty and undergraduates, that the other groups are not aware of what is available to them.

The undergraduates expressed frustration that the collection is outdated and that they have problems finding books. One member thought the question about a "wish list" of library resources was unfair because all his information seeking was linked to fulfilling class requirements. This response is in contrast to the graduate student and faculty groups who define their information seeking as "research." Interestingly, 
undergraduates mentioned that library instruction sessions about the library resources were helpful. This comment will be useful in discussions with faculty members and supports the Library's request that librarians be invited into more undergraduate research classes, so they can instruct students about library resources.

In response to the question "How do you seek out information?" undergraduate students said they "start with CSU Library's web page, then Google Scholar." Graduate students indicated they "start with CSU as the first resource for research, followed by OhioLINK and finally, Cleveland Public Library System." These responses contradict the results of OCLC's 2006 report, College Students' Perceptions of Libraries and Information Resources, which examines the information-seeking habits and preferences of international college students. Their "survey findings indicate that 89 percent of college student information searches begin with a search engine. . . . Library searches were selected by just 2 percent of students as the source used to begin an information search." (De Rosa 2006). The bias of the contradiction may reflect the nature of the students participating in the focus groups-students recommended by librarians or faculty because of their interest or prowess in the use of the Library.

In response to the question: "If you were going to do research in an 'ideal world,' what would you need for resources?" Respondents in each focus group (not including Special Collections) listed specific journal titles or access to specific databases. Access to full-text articles rather than abstracts was desirable. The focus group on Special Collections expanded their "ideal world" to include outreach activities to capture and record more local history resources, giving their concept of "collection" a more participatory flavor-a reflection of the enthusiasm shared by members of the focus group.

Three of the big four-future expenditures on electronic resources, website design and marketing the University Library-identified as "patterns" by Whipple and Freyn are topics at the center of many discussions in the Library. The transition from print to online resources and the concomitant shift in expenditures continues at an increasing rate; with this momentum OhioLINK is becoming a greater broker of resources that are selected by the consortium rather than the local library. Website design in these days of Web 2.0 influence is a topic of serious discussion, even though the Library had a major change in the website during the last year. The Library now has a marketing team that works diligently to market the Library in a variety of ways; although according to these focus groups, more marketing must be done. 
The recommendation on "resource acquisition training" needs further exploration and fits perfectly with the Library's current outreach initiatives in academic departments. Subject librarians are embedded in some departments and learning communities. Closer contact with faculty and students provides opportunities to communicate about resources-what is available and what is needed. The types of information requested in the focus group included information about the book and journal request process, budget information, prioritization of resources and monies, the number of teachers or student recommendations required to justify a purchase, notification of new texts or journals in their field, establishment of an obsolete file of items no longer subscribed to, establishment of an overlap communication tool with other departments on resources, training programs on existing resources, and notification of journals going from paper to electronic format.

\section{CONCLUSION}

Pursuing an area of concern in LibQUAL $+{ }^{\mathrm{TM}}$ surveys by conducting focus group sessions on the Library's collections, access to it and its use was an appropriate and informative research activity, which yielded usable results. The results from this research will be shared with colleagues in the Library, will be reported to the Office of Student Learning Assessment in the next assessment cycle and will be incorporated into the Library's strategic planning process in January 2008.

Three of the patterns identified by Whipple and Freyn, that is, future expenditures on electronic resources, website design and marketing the University Library, reinforce initiatives that have a significant role in the Library's current strategic plan. These initiatives will take on extra emphasis with the focus group data to support them. The fourth pattern, resource acquisition training, must be explored further. During the 2006-2007 academic year the Library initiated outreach activities to academic departments, schools and colleges. Expanding the outreach emphasis in the 2007-2008 academic year will provide more opportunities to work with faculty on the process of acquiring resources. Facilitating effective communication about the needs of users from the users themselves will be an important element in this exploration. The team will develop ways for the faculty to be more involved in building the collection. 
Finally, the team recognizes the merits of this type of research on the Library's collection and plans to conduct additional focus group sessions using the same set of discussion questions in the coming year. The use of focus groups for collection assessment is a fruitful complement to information gathered in LibQUAL + TM surveys. If "focusness" helped the baseball player succeed, the Library plans to do even better to serve Cleveland State Library users.

\section{REFERENCES}

Becher, Melissa L. 2005. Using student focus groups to inform library planning and marketing. College \& Undergraduate Libraries 12 (1/2): 1-18.

Cleveland State University. Academic Vision 2009. http://www.csuohio.edu/uspc/ vision2009.html (accessed September 5, 2007).

Cleveland State University. Book of Trends 2006. http://www.csuohio.edu/iraa/bot/ BOT_06.pdf (accessed September 7, 2007).

Cleveland State University. Office of Student Learning Assessment. http://www. csuohio.edu/assessment/index.html (accessed September 5, 2007).

De Rosa, Cathy. 2006. College students' perceptions of libraries and information resources: A report to the OCLC membership. Dublin, Ohio: OCLC Online Computer Library Center.

Hartley, R. J. 2006. Users and union catalogues. Journal of Librarianship and Information Science 38 (1): 7.

LibQUAL+ TM: Defining and promoting library service quality. http://www.libqual. org/About/Information/index.cfm (accessed September 5, 2007).

Olson, Christine. 2006. Making marketing materialize: 10 pointers for better focus groups. BF Bulletin no. 132: 14-15.

Ryan, Gerard, and Mireia Valverde. 2005. Waiting for service on the Internet. Internet Research 15 (2): 220-240.

Wakimoto, Jina Choi. 2006. The myths and realities of SFX in academic libraries. Journal of Academic Librarianship 32 (2): 127-136.

Weber, Michael A. 2006. What do faculty want?: A focus group study of faculty at a mid-sized public university. Library Philosophy \& Practice 9 (1):1-8.

\section{FURTHER READING}

Anderson, Kent. 2006. Ask and they shall deceive: How what we ask drives what they tell us, and why it's mostly useless. Learned Publishing 19(3): 209-216. 